\title{
Review of AC-DC power electronic converter topologies for power factor correction
}

\author{
R. Sasikala ${ }^{1}$, R.Seyezhai ${ }^{2}$ \\ ${ }^{1}$ Department of Electrical and Electronics Engineering, Research Scholar, Sathyabama University \\ ${ }^{2}$ Department of EEE, Associate Professor, SSN College of Engineering
}

\begin{tabular}{l}
\hline \hline Article Info \\
\hline Article history: \\
Received Nov 21, 2018 \\
Revised Mar 1, 2019 \\
Accepted Apr 28, 2019 \\
\hline Keywords: \\
Bridgeless SEPIC \\
CUK, FLYBACK \\
Displacement Factor \\
Interleaved SEPIC \\
LED \\
Power Factor correction \\
SEPIC \\
\hline
\end{tabular}

\begin{abstract}
Increased harmonic content and low power factor in power systems caused by power converters have been of great concern. To overcome this, several converter topologies employing advanced semiconductor devices and control schemes have been proposed. The aim of this paper is to identify a low cost, small size, efficient and reliable ac to dc converter to meet the input performance index of uninterrupted power supply. In this paper, comparison between three converters namely AC-DC Cuk rectifier, Fly back converter \& Interleaved SEPIC converter have been carried out. For the above converters both bridged and bridgeless topologies have been analysed. The working of all the three types of converter has been illustrated with relevant waveforms followed by the simulation results. Comparison of the three converters have been done based on the parameters namely Displacement Factor, Supply Power Factor\& supply THD. The results are verified.
\end{abstract}

Copyright (c) 2019 Institute of Advanced Engineering and Science. All rights reserved.

\section{Corresponding Author:}

R. Sasikala,

Department of Electrical and Electronics Engineering,

Research Scholar, Sathyabama University.

Email: sasi.ped@gmail.com

\section{INTRODUCTION}

To get unity power factor and reduced total harmonic distortion (THD), power factor correction (PFC) is needed. High power quality is required for power supply systems in order to fulfil the international standards such as IEEE-519/ IEC 61000-3-2/ EN 61000-3-2. Approximately 25\% of overall electrical energy is used in the world for lighting purpose. Incandescent bulb consumes much power and currently these bulbs have been replaced by LEDs to reduce the energy consumption. LED offer many advantages such as: extremely long life, i.e. 10,000 hours, extreme robustness as there is no glass component or filament, no external reflector, modular construction, relatively high efficiency, no UV or IR output and they can be dimmed smoothly from full output to zero state [1]. Requiring the achievement of long service life of the LED lamps, there is always a need for a stabilised DC current source to supply the LEDs [2]. Switched mode DC-DC converters are used to convert unregulated dc input into a controlled dc output at a desired voltage level.

The active PFC is the commonly used method for power factor correction to achieve a unity power factor and less harmonics in the supply current [3]. Normally the active PFC circuit consists of bridge rectifier and DC-DC converter. During turn on, probably three semiconductor devices will be in conduction. This gives conduction losses across diode bridge and reduces the system efficiency, Significant conduction loss, caused by the forward voltage drop across the bridge diode, considerably reduces the converter's efficiency, especially at a low line input voltage [4]. In order to increase the efficiency, bridgeless PFC circuits are designed. However, losses due to large number of semiconductors are reduced by removing the diode rectifier in the supply side. Recently, several bridgeless PFC rectifiers have been introduced to improve 
the rectifier power density and/or reduce noise emissions via soft-switching techniques or coupled magnetic topologies [5].

A bridgeless PFC circuit allows current to flow through less number of switching devices. Accordingly, conduction losses are considerably reduced and higher efficiency can be obtained. There are mainly two types of DC to DC converters namely isolated and non-isolated [6].Some converters do not have any isolation transformers between source and load side namely the classical buck, boost, buck-boost and cuk converter. Another type is DC to DC converters with isolation. A transformer is provided for the isolation between the input and output stage. The DC to DC converter is again divided into two types based on polarity of transformer core excitation [7]. Commonly used DC to DC converters with isolation are Fly back converter Forward converter, Full bridge converter, Half bridge converter and Push-Pull converter etc .From the above different types of converter power factor correction is done for following converters namely ACDC Cuk rectifier, Flyback converter \& Interleaved SEPIC Converter.

\section{AC-DC CUK RECTIFIER}

\subsection{Bridge cuk rectifier}

Figure 1 shows the bridged cuk circuit. In this converter, the output voltage can be increased or decreased according to variation in duty ratio. The cuk converters have better efficiency and reduced noise. It is used for applications such as automotive, consumer-electronics, electric drives and renewable systems. The single phase AC voltage is given to the diode bridge rectifier. Then the power is transferred from the rectifier to the cuk converter [8-9]. The energy flow is bidirectional in the cuk converter. The cuk converter consists of two inductors, two capacitors, switch used as transistor, diode. It consists of an input voltage source Vs ,a MOSFET switch S1, an anti-parallel diode D, a capacitor C1 for transferring energy, a capacitor $\mathrm{C} 2$ for storing energy, two inductors L1 and L2, and a load resistor R. Let V1 and V2 be the voltages across the capacitors $\mathrm{C} 1$ and $\mathrm{C} 2$, respectively [10]s. Let I1 and I2 be the currents through the inductors L1 and L2, respectively. When Switch S is ON, the circuit is in charging mode. When Switch $\mathrm{S}$ is open, the circuit is in discharging mode. The inductor on the input acts as a filter for the dc supply, to prevent large harmonic current. Cuk converter has the characteristics of both Buck and Boost Converter.

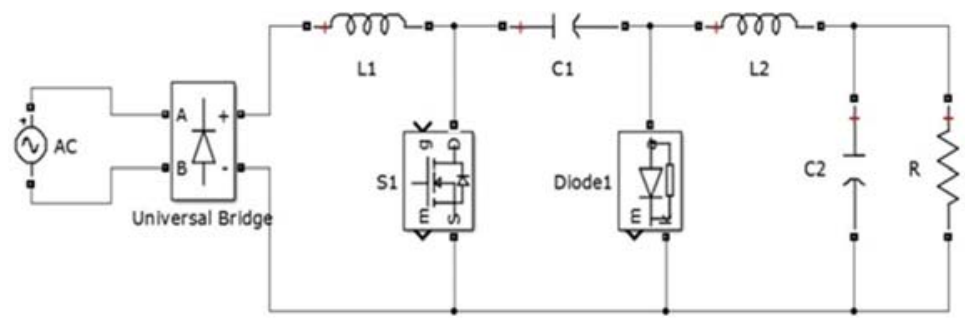

Figure 1. Bridged CUK rectifier

\subsubsection{Design Equation for Cuk Converter}

$$
\begin{aligned}
& \frac{\text { Vout }}{\text { Vin }}=-(D \mid 1-D) \\
& \Delta_{i L 1}=\frac{\text { DVin }}{f L 1} \\
& \Delta_{i L 2}=\frac{(1-D) \text { Vout }}{f L 2} \\
& \Delta_{V C 1}=\frac{\text { VoutD }}{R C 1 f}
\end{aligned}
$$

Using (1)-(4) the simulation parameters are calculated. The Input voltage $=24 \mathrm{~V}$, Output voltage $=$ $48 \mathrm{~V}$, Supply frequency $=50 \mathrm{HZ}$, Switching frequency $=50 \mathrm{KHZ}$, Duty cycle $=0.5$, Inductor L1 $=7.5 \times 10^{-5}$, $\mathrm{L} 2=2.5 \times 10^{-5}$ and Capacitor $\mathrm{C} 1=\mathrm{C} 2=1 \mu \mathrm{F}$

\subsubsection{Simulation results of bridged cuk converter}

Review of AC-DC power electronic convertertopologies forpower factor correction (R. Sasikala) 
The simulation results of bridged Cuk Rectifier are shown in Figures 2-4.

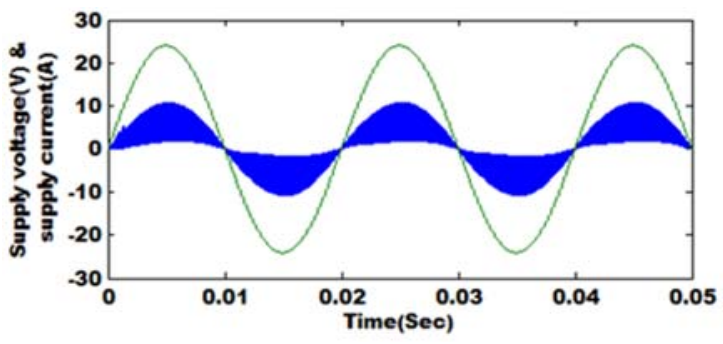

Figure 2. Supply voltage and supply current of bridged cuk rectifier

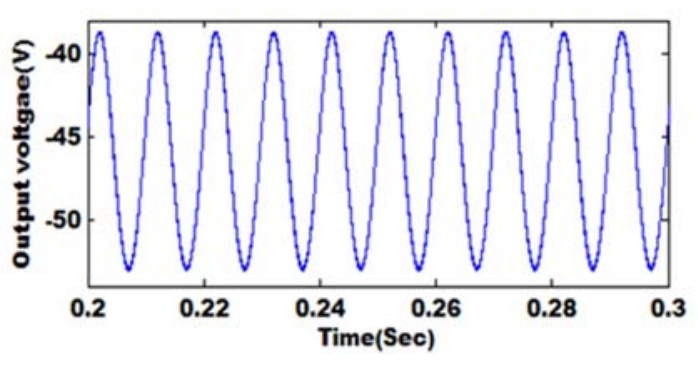

Figure 3. Output voltage of bridged cuk rectifier

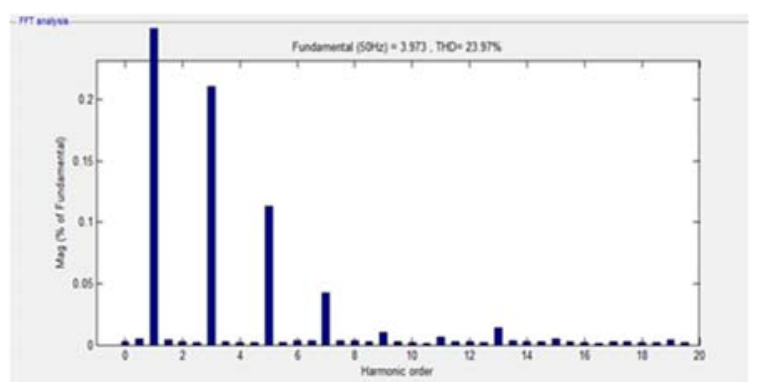

Figure 4. FFT analysis of supply current of bridged cuk rectifier

From Figure 2, it is clear that the input line current is almost in phase with the input line voltage. Figure 3 shows the output voltage waveform. Figure 4 shows the line current harmonic spectrum and the calculated value for power factor is 0.9724 .

\subsection{Bridgeless cuk rectifier}

Figure 5 shows the proposed bridgeless Cuk topology. In this converter consists of single input stage for both the positive and negative half cycles of the line voltage. The circuit consists of three capacitors, four inductors, two MOSFET switches and four diodes. In the output end, the load is resistive to maintain a unity power factor [11-13]. It has two stage of circuits connected to the input side each stage operates during each half cycle of input voltage. The bridgeless converter uses two switches (S1\& S2). S1 is turned on/off during the positive half-line cycle while S2 is switched on/off during the negative half cycle. The converter has high power factor when operating in discontinuous inductor conduction mode (DICM) because the line current is proportional to the input voltage. The proposed modified Cuk rectifier is designed for the following operating point: peak input voltage of $24 \mathrm{Vrms}$, line frequency of $50 \mathrm{~Hz}$, output voltage of $48 \mathrm{~V}$ and switching frequency of $50 \mathrm{kHz}$.

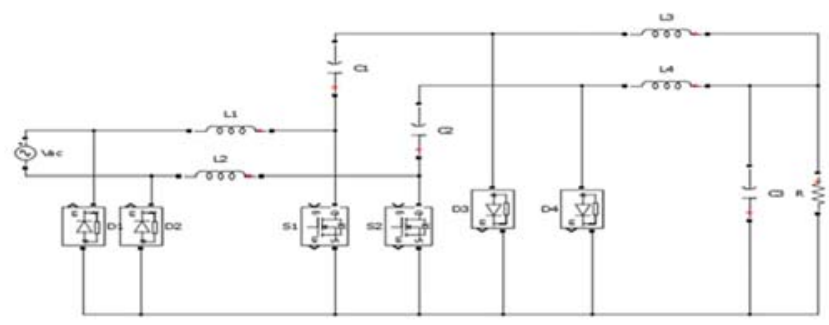

Figure 5. Bridgeless cuk rectifier 


\subsubsection{Simulation results of bridgeless cuk rectifier}

The simulation results of Bridgeless Cuk Rectifier are shown in Figures 6-8.

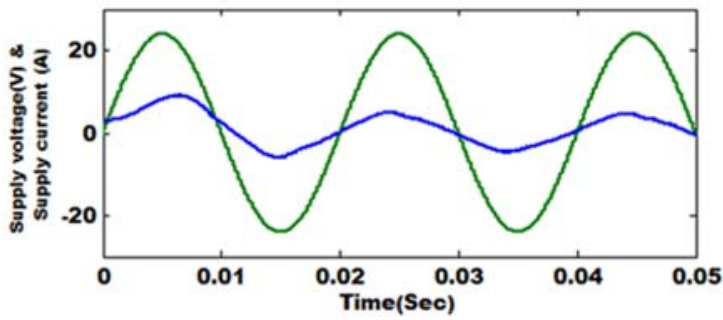

Figure 6. Supply voltage and supply current of bridgeless cuk rectifier

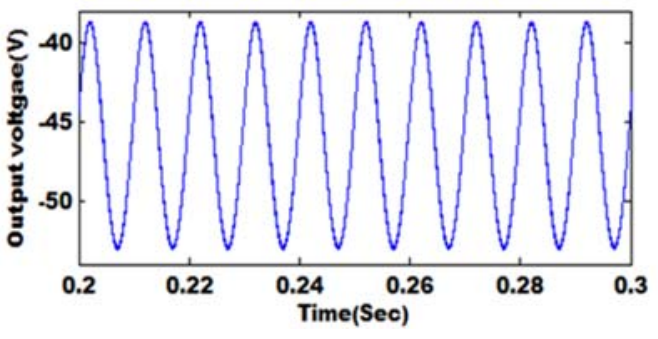

Figure 7.Output voltage of bridgeless cuk rectifier

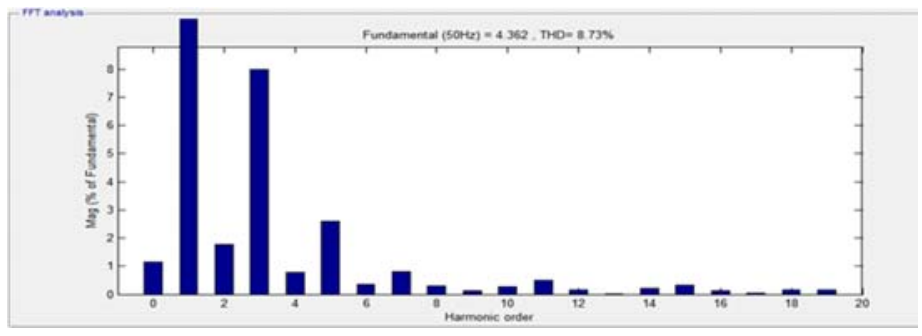

Figure 8. FFT analysis of supply current of bridgeless cuk rectifier

From Figure 6, it is clear that the input line current is in phase with the supply line voltage. Figure 7 shows the output voltage waveform. Figure 8 shows the line current harmonic spectrum and the calculated value for power factor is 0.9832

Table 2. Comparison of bridge \& bridgeless cuk converter

\begin{tabular}{ccc}
\hline Parameter & Bridged cuk converter & Bridgeless cuk converter \\
\hline Displacement factor & 0.9726 & 0.9869 \\
Supply power factor & 0.9724 & 0.9832 \\
Supply thd & $23.97 \%$ & $8.73 \%$ \\
\hline
\end{tabular}

From the Table 2, it is clear that the power factor of bridgeless cuk converter is high when compared to the bridged cuk converter. The supply THD is also less for bridgeless cuk converter.

\section{FLYBACK CONVERTER}

\subsection{Bridged flyback rectifier}

Figure 9 shows the bridged Fly back converter. This is one type of isolated converters used for both low and moderate power level. The circuit consists of front end bridge followed by fly back topology. The circuit consists of diode bridge rectifier, MOSFET switch, isolated transformer, diode, capacitor and resistor. The isolation between the control switch and load is provided by transformer. A fast switching device ('S1'), like a MOSFET, is used with fast dynamic control over switch duty ratio (ratio of ON time to switching timeperiod) to maintain the desired output voltage [14].

In the circuit the winding leakage inductances should be neglected. On- state voltage drops of switches and diodes are neglected. The windings, the transformer core, capacitors etc. are assumed loss-less. The input dc supply is also assumed to be ripple-free [15]. The energy is stored in the primary Lp inductance of the transformer during the time the power switch is on, and transferred to the secondary output when the power switch is off. If $\mathrm{n}=\mathrm{Np} / \mathrm{Ns}$ is the turns ratio of the transformer Flyback topology is dedicated to multiple low cost output SMPS as there is no filter inductor on the output. 


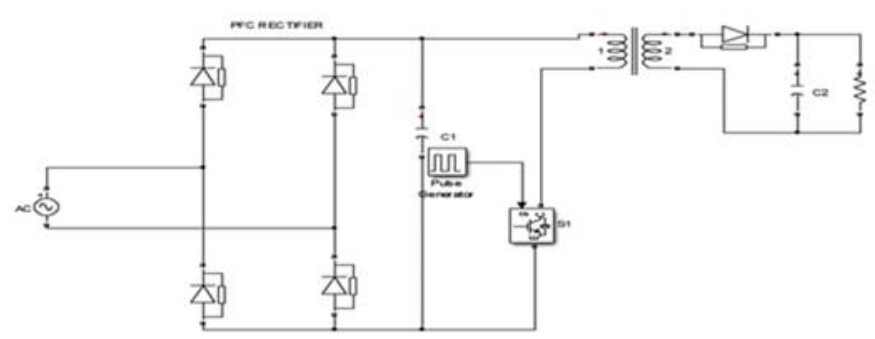

Figure 9. Bridged flyback converter

\subsubsection{Design equation of flyback converter}

Setting a flyback voltage Vor

$V_{O r}=V o \times N p / N s=$ Ton $/$ Toff $\times$ Vin

$\frac{N p}{N s}=\frac{V o r}{V o}$

Calculating the secondary winding inductance Ls

$$
\begin{aligned}
& L_{S}=\frac{(\text { Vout }+ \text { Vf }) \times(1-\text { Duty }) 2}{2 \times \text { Iomax } \times \text { fswmax }} \\
& D U T Y=\frac{\text { Vor }}{\text { Vin }+ \text { Vor }}
\end{aligned}
$$

Calculating the secondary winding inductance Lp

$$
L_{P}=L_{S} \times(N p \mid N s) 2
$$

Employing the equations (5)-(9), the converter is designed and the parameters are The Input voltage $=24 \mathrm{~V}$, Output voltage $=48 \mathrm{~V}$, Supply frequency $=50 \mathrm{HZ}$, Switching frequency $=50 \mathrm{KHZ}$, Duty cycle $=0.5$, and Capacitor $\mathrm{C} 1=\mathrm{C} 2=2200 \times 10^{-5} \mathrm{~F}$.

\subsubsection{Simulation results of bridged flyback converter}

The simulation results of bridged Flyback converter are shown in Figures 10-12.

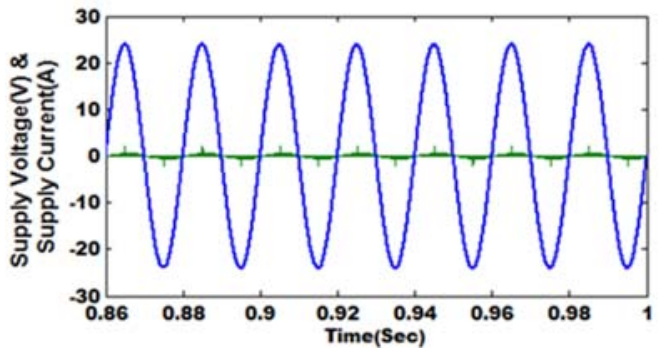

Figure 10. Supply voltage and supply current of bridged flyback converter

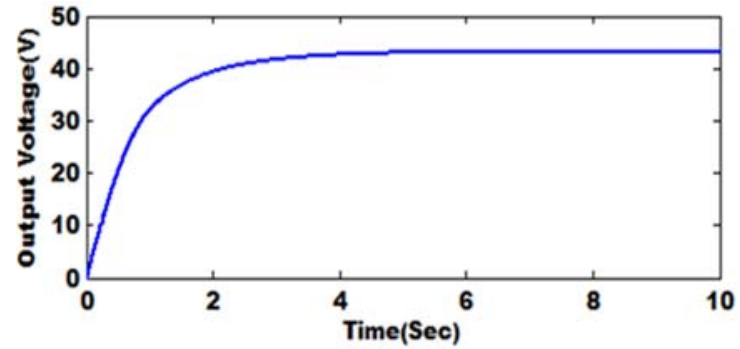

Figure 11. Output voltage of bridged flyback converter 


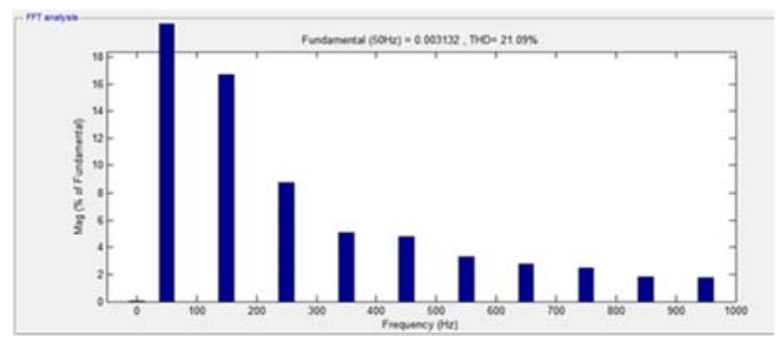

Figure 12. FFT analysis of supply current of bridged fly back converter

From Figure 10, it is clear that the input line current isalmost in phase with the input line voltage. Figure 11 shows the output voltage waveform. Figure 12 shows the line current harmonic spectrum and the calculated value for power factor is 0.75 .

\subsection{Bridgeless Flyback Rectifier}

Figure 13 shows the circuit configuration of improved bridgeless flyback rectifier with bidirectional switch. Bidirectional switch cell is added for the rectification process. Bidirectional switch cell is formed by the back to back connection of two MOSFET switches[16-17].A few more circuit components are added to the conventional flyback rectifier circuit in order to compensate the elimination of four bridge diodes. Mainly three modifications are done in the circuit. Bidirectional switch cell, Dual transformer output windings \& Adding D2 to the secondary side

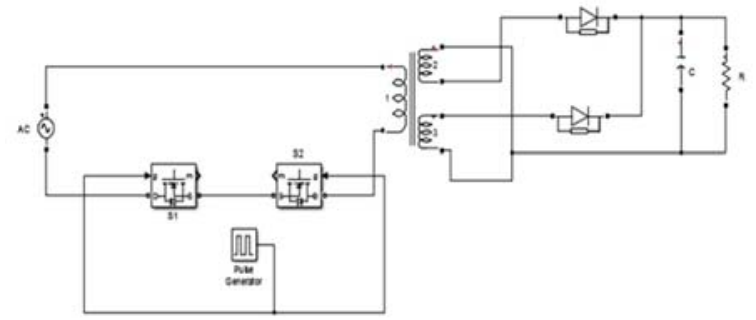

Figure 13. Bridgeless flyback converter

\subsubsection{Simulation results of Bridgeless Flyback converter}

The simulation results of bridgeless Flyback converter are shown in Figures14-16. Figure 14, it is clear that the input line current almost in phase with the input line voltage in sinusoidal manner. Figure 15 shows the output voltage waveform. Figure16 shows the line current harmonic spectrum and the calculated value for power factor is 0.854 . it is clear that the power factor of bridgeless fly back converter is high when compared to the bridged fiyback converter as shown in Table 4. The supply THD is also less for Bridgeless Flyback Converter.

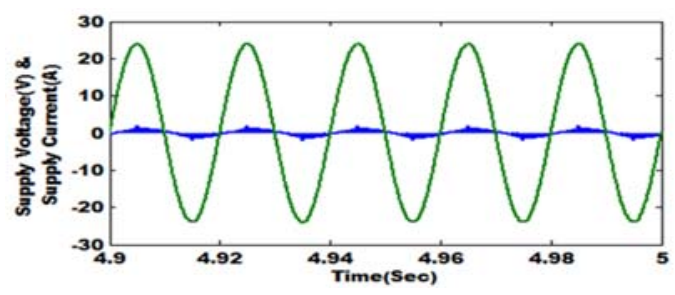

Figure 14. Supply voltage and supply current of bridgeless flyback converter

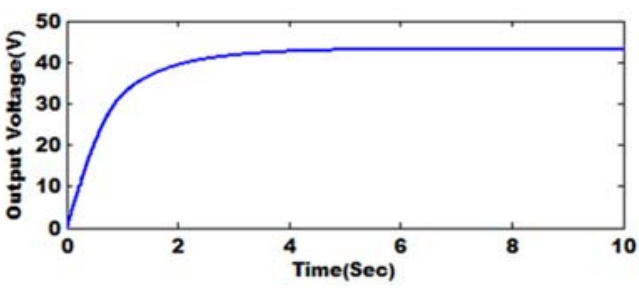

Figure 15. Output voltage of bridgeless flyback converter 


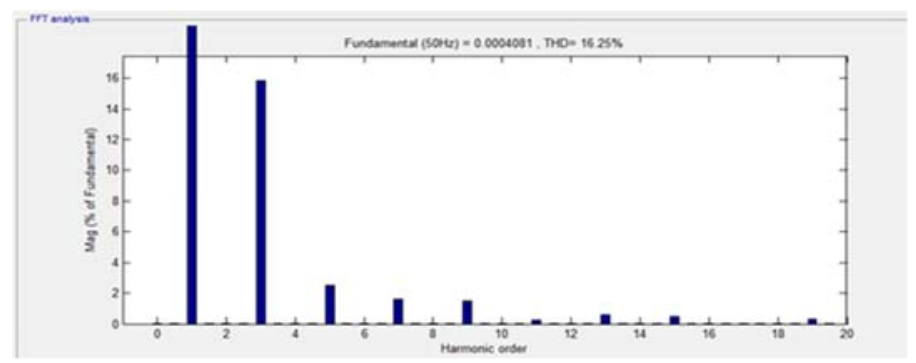

Figure 16. FFT analysis of supply current of bridgeless flyback converter

Table 4.Comparison of bridge \& bridgeless flyback converter

\begin{tabular}{ccc}
\hline Parameter & Bridged flyback converter & Bridgeless flyback converter \\
\hline Displacement factor & 0.7665 & 0.8648 \\
Supply power factor & 0.75 & 0.854 \\
Supply thd & $21.09 \%$ & $16.25 \%$ \\
\hline
\end{tabular}

\section{INTERLEAVED SEPIC CONVERTER}

\subsection{Bridged interleaved sepic converter}

Interleaving of DC-DC converter is widely used in power supplies and power factor correction circuits. Since in high power application, the voltage and current stress of the gadget can go past the limit with the goal that the power gadget can't deal with. In this case, paralleling the devices can provide the solution, but one major concern of this solution is the current sharing and voltage sharing. There is another arrangement, which is paralleling the converters rather than power gadgets [18]. By paralleling the converters i.e., the interleaved converter is proposed as it leads to cancellation of ripple at the input and output side. Single-ended primary-inductor converter (SEPIC) is a buck-boost derived converter, which could step down and step up the input voltage. The fundamental preferred standpoint of interleaving is the decrease of input current and yield reduced voltage ripple [19]. Open loop operation of both bridge and bridgeless Interleaved Sepic converter is carried out.

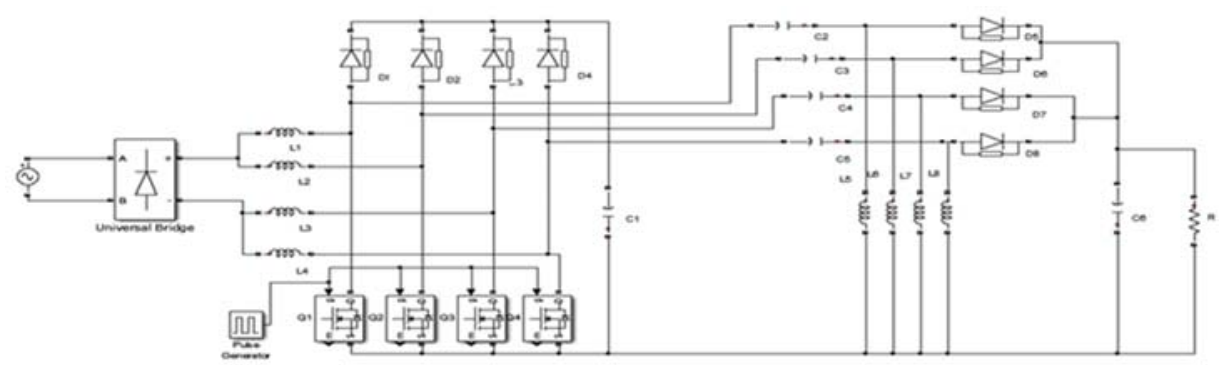

Figure 17. Bridged Interleaved Sepic Converter

Design Equation for interleaved sepic converter

$$
\begin{aligned}
& \text { Output Voltage } \mathrm{V}_{\mathrm{o}}=\frac{D \text { Vin }}{(1-D)} \\
& \text { Boost inductor L1, L2 }=\frac{D V i n}{f_{S(\Delta I L i)}} \\
& \text { Intermediate Capacitor C1.C2 }=\frac{D V d c}{\left[R f_{S}(\Delta V c i)\right]} \\
& \text { Output filter inductor L3, L4 }=\frac{(1-D) V d c}{[f s(\Delta I L o)]}
\end{aligned}
$$


Output filter capacitor $\mathrm{Co}=\operatorname{Iav} /(2 w \Delta V d c)$

From the (11)-(14) the simulation parameters are calculated is given by Input voltage $=24 \mathrm{~V}$, Output voltage $=48 \mathrm{~V}$, Supply frequency $=50 \mathrm{HZ}$, Switching frequency $=50 \mathrm{KHZ}$, Duty cycle $=0.5$, Inductor $=\mathrm{L} 1, \mathrm{~L} 2$, $\mathrm{L} 3, \mathrm{~L} 4=3.6 \mathrm{mH}$ and Capacitor $\mathrm{C} 1, \mathrm{C} 2, \mathrm{C} 3, \mathrm{C} 4=6.7 \mathrm{mF} \mathrm{C0}=3000 \mathrm{mF}$.

\subsubsection{Simulation results of bridged interleaved sepic converter}

The Simulation results of Bridged Interleaved Sepic Converter are shown in Figures 18-20. Figure 18 , it is clear that the input line current almost in phase with the input line voltage in sinusoidal manner. Figure 19 shows the output voltage waveform. Figure 20 shows the line current harmonic spectrum and the calculated value for power factor is 0.9349 .

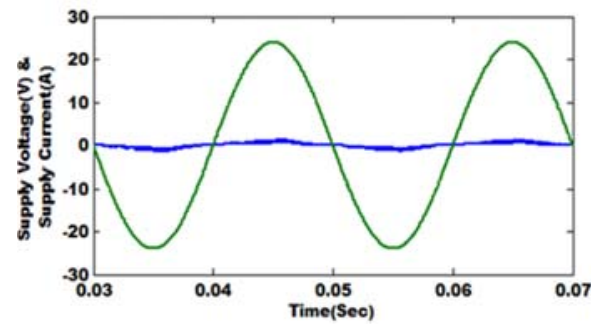

Figure 18.Supply voltage and supply current

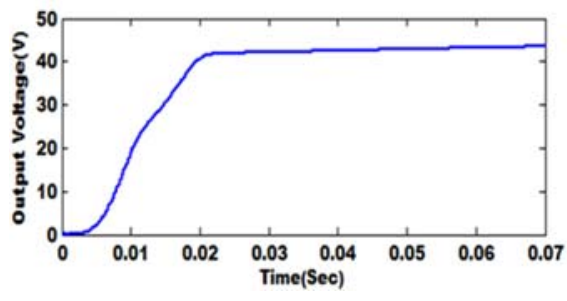

Figure 19. Output voltage

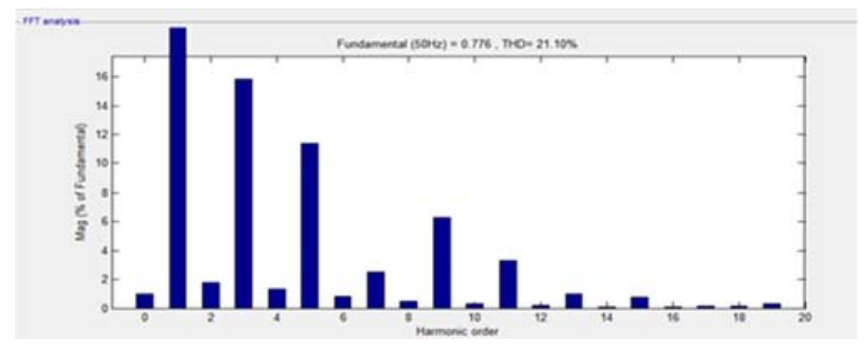

Figure 20. FFT analysis of supply current of bridged interleaved sepic converter

\subsection{Bridgeless interleaved sepic converter}

The bridgeless Interleaved SEPIC topology combines the feature of both the bridgeless topology and the interleaved structure. Bridgeless configuration improves the efficiency as the high conduction loss caused by the high forward voltage drop of the diode bridge is absent. So the heat management problem caused by the input diode rectifier stage is also solved. The conduction losses are greatly reduced due to the presence of fewer number of semiconductor devices in each conduction path. This topology uses two extra MOSFETs and fast diodes, instead of the four slow diodes in the bridge rectifier stage. Thus this topology can exhibit maximum efficiency due to the combined merits of interleaving and the bridgeless structure the interleaving topology divides the current stress in the semiconductor devices and the ripple in the supply current is also greatly minimized [20].

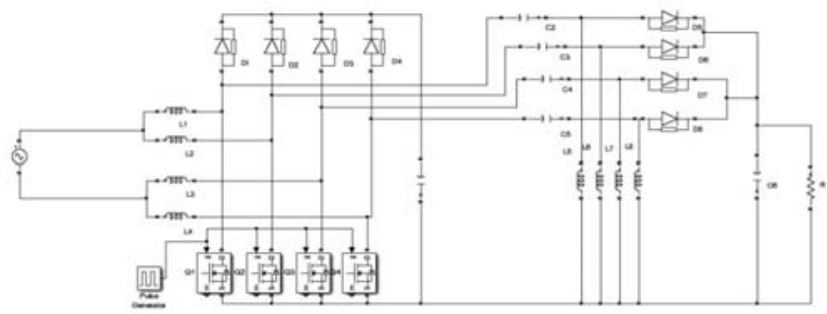

Figure 21. Bridgeless interleaved sepic converter 


\subsubsection{Simulation results of bridgeless interleaved sepic converter}

The Simulation results of Bridgeless Interleaved Sepic Converter are shown in Figures 22-24. As shown in Figure 22, it is clear that the input line current almost in phase with the input line voltage in sinusoidal manner. Figure 23 shows the output voltage waveform. Figure 24 shows the line current harmonic spectrum and the calculated value for power factor is 0.9885 .

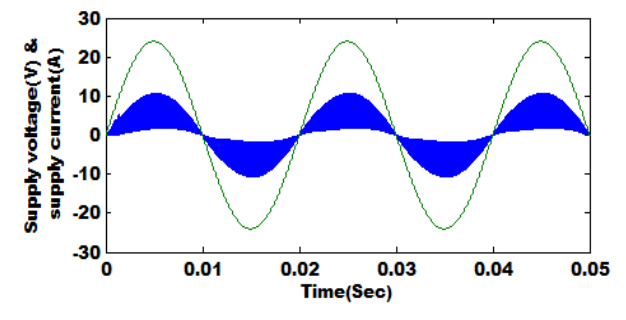

Figure 22. Supply voltage and supply current of bridgeless interleaved sepic converter

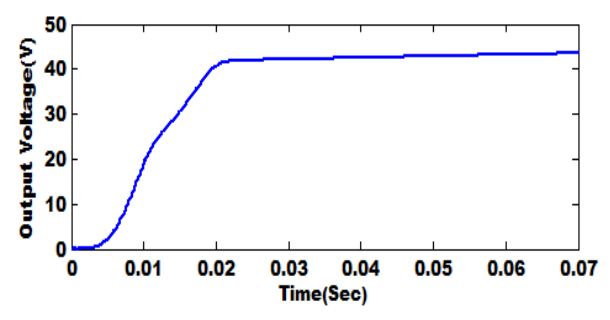

Figure 23. Output voltage of bridgeless interleaved sepic converter

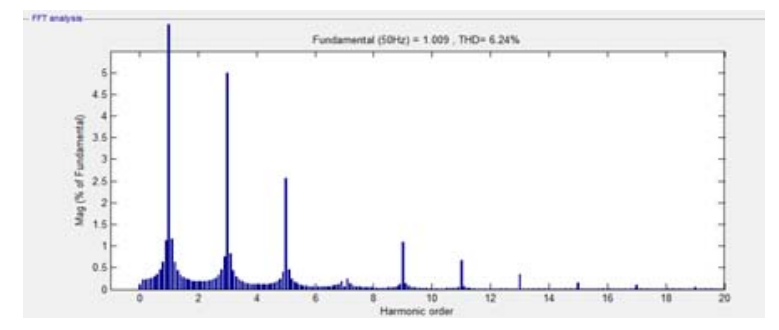

Figure 24. FFT Analysis of supply current of bridgeless interleaved sepic converter

Table 6 Comparison of bridge \& bridgeless interleaved sepic converter

\begin{tabular}{ccc}
\hline parameter & bridge interleaved sepic converter & bridgeless interleaved sepic converter \\
\hline displacement factor & 0.9351 & 0.9813 \\
supply power factor & 0.9349 & 0.9885 \\
supply thd & $21 \%$ & $6.24 \%$ \\
\hline
\end{tabular}

From Table 6, it is clear that the power factor of bridgeless interleaved sepic converter is high when compared to the bridged cuk converter. The supply THD is very less in the range of $6.24 \%$ for bridgeless interleaved sepic converter as shown in Table 7.

Table 7. Comparison of ac-dc PFC topologies

\begin{tabular}{lll}
\hline Topology & Power factor & Supply current thd \\
\hline Bridgeless cuk converter & 0.9832 & $8.73 \%$ \\
Bridgeless flyback converter & 0.854 & $16.25 \%$ \\
Bridgeless interleaved sepic converter & 0.9885 & $6.24 \%$ \\
\hline
\end{tabular}

\section{CONCLUSION}

A comprehensive study and analysis of bridged and bridgeless AC-DC rectifier topologies have been investigated in this paper. Analysis is done based on the performance parameters such as power factor, supply current THD and displacement factor. From the above analysis, the power factor of bridgeless Interleaved Sepic converter is 0.9885 which is approximately closer to the unity power factor when compared with the other two topologies. The supply THD is also very less around $6.24 \%$ for the bridgeless Interleaved Sepic converter which satisfies the IEC standards. Hence, it is clear that the bridgeless Interleaved SEPIC converter shows a better performance for power factor correction applications. 


\section{REFERENCES}

[1] VivekNaithani and A.N.Tiwari and SmitaDobhal, "Simulation of sepic converter fed Leds,"International Journal of Engineering Science and Technology, vol. 4, no. 03, March, pp. 1015-1020, 2012.

[2] Pospisilik, Martin \& ADAMEK, Milan "Led based universal lighting system"Annals of DAAAM for 2012 \& Proceedings of the 23rd International DAAAM Symposium, Volume 23, No.1, ISSN 2304-1382, pp. 0649 - 0652 May 2012.

[3] R.Sreemallika,R.Seyezhai "Investigation of closed loop current control strategies for bridgeless interleaved sepic converter"An International Journal (ELELIJ), vol. 3, no. 3, pp. 63 - 70,01 August 2014

[4] SangCheolMoon,Gwan-Bon Koo andGun-Woo Moon "A New Control Method of Interleaved Single-Stage Flyback AC-DC Converter for Outdoor LED Lighting Systems"IEEE transactions on power electronics, vol. 28, no. 8, pp. 4051 - 406 Aug 2013

[5] K. T. Mok, Y. M. Lai, and K. H. Loo, "A single-stage bridgeless powerfactor- correction rectifier based on flyback topology,” in Proc.IEEE 29th Int. Telecommun. Energy Conf, pp. 1-6, 2011.

[6] MirkoBodetto, Abdelali El Aroudi, Angel, "Design of AC-DC PFC High-Order Converters With Regulated Output Current for Low-Power Applications," IEEE Trans. Power Electron., vol. 31, no. 3, pp. 2012-2025, March 2016.

[7] N. Rajasingam , S. N. Deepa“A Unique SEPIC converter based Power Factor Correction method with a DCM Detection Technique"IEEE transactions on power electronics, vol. 11, Issue 4 Ver. III , PP 01-06 Aug 2013, Jul. Aug. 2016

[8] Anmol RatnaS axena, Ashima Kulshreshtha, Praveen Bansal,"Universal bus digitally controlled front end damped PFC Cuk converter as LED drivers," in power Electronics, Intelligent control and Energy Systems, Feb, Electronic ISBN: 978-1-4673-8587-9, 2017.

[9] RajeswariR.V, Geetha A"Comparison of Buck-Boost andCUK Converter Control UsingFuzzy Logic Controller." International Journal of Innovative Research in Science, Engineering and Technology, Vol. 3, March, pp.208-212, 2014

[10] M. Sujith and S. Asokkumar, "Performance Improvement of Bridgeless Cuk Converter Using Hysteresis Controller," International Journal of Electrical Engineering, ”vol. 6, no. 1, April, pp. 1-10, 2013.

[11] Hong-Tzer Yang, Hsin-Wei Chiang, and Chung-Yu Chen, "Implementation of Bridgeless Cuk Power FactorCorrector with Positive Output Voltage,"IEEE Transactions on Industry Applications, Vol. 51, No. 4, July/August 2015.

[12] D.Gokilapriya, R.Karthigayini, "A Bridgeless Cuk Converter for Power FactorCorrection and Speed Control in BLDC Motor,"International Journal of Advanced Research in Electrical, Electronics and Instrumentation Engineering, vol. 3, pp. 9597- 9606. May. 2014.

[13] Yuequan Hu, Laszlo Huber, and Milan M. Jovanović, "Single-Stage Flyback Power-Factor-Correction Front-End for HB LED Application,"International Journal of Advanced Research in Electrical, Electronics and Instrumentation Engineering, Delta Power Electronics Laboratory, Delta Products Corporation, IEEE, 2009.

[14] Gaurav B. Patil, Paresh J. Shah. "A Review on Single Stage Forward and Fly back Converter toImprove its Performance." International Journal of Engineering and Techniques, vol. 2, pp. 100- 108.April 2016.

[15] Sumy Thomasi, and RakheeR,"Control of Bridgeless Flyback Converter." International Journal of Engineering Research \& Technology (IJERT) Vol.4, no. 4, pp.739-743, http://www.scirp.org/journal/cs, April 2015.

[16] H. Hu, X. Fang, F. Chen, Z. J. Shen, and I. Batarseh, "A Modified High- Efficiency LLC Converter With Two Transformers for Wide Input-Voltage Range Applications," IEEE Trans. Power Electron., vol. 28, no. 4, April, pp. 1946-1960, 2013.

[17] A. Inba Rexy, R. Seyezhai "Investigation of current control techniques of AC-DC Interleaved Boost PFC converter", Circuits and Systems; Circuits and Systems, April, 7, 307-326, 2016.

[18] Dr R.Seyezhai, R.Sreemallika "A Novel SEPIC Power Factor Correction Converter for HBLED Applications," MAGNT Research Report (ISSN. 1444-8939), vol. 4, no. 3, pp. 135-141, 2017

[19] Ismail, E. H; "Bridgeless SEPIC Rectifier With Unity Power Factor and Reduced Conduction Losses", IEEE Transactions on Industrial Electronics, Vol. 56, Issue 4, April Page(s):1147- 1157, 2009. 